\title{
A Novel Technique for Mapping the Vascularity of Labia Minora Prior to Labiaplasty: Cold Light Illumination
}

\author{
Neuartiges Verfahren zur Darstellung der Vaskularität der inneren \\ Schamlippen vor der Labioplastik: Einsatz von Kaltlichtbeleuchtung
}

(c) (1) $\ominus$

Authors

Aski Ellibes Kaya', Ozan Dogan², Murat Yassa ${ }^{3}$, Alper Basbug ${ }^{1}$, Eray Çalışkan ${ }^{4}$

Affiliations

1 Department of Obstetrics and Gynecology, Duzce University Hospital, Duzce, Turkey

2 Department of Obstetrics and Gynecology, Health Sciences University, Sisli Hamidiye Etfal Research and Training Hospital, Istanbul, Turkey

3 Department of Obstetrics and Gynecology, Health Sciences University, Fatih Sultan Mehmet Training and Research Hospital, Istanbul, Turkey

4 Department of Obstetrics and Gynecology, Bahçeşehir University School of Medicine, Istanbul, Turkey

\section{Key words}

labiaplasty, vascularity of labia minora, cold light illumination, labia minora, labia minora reduction

\section{Schlüsselwörter}

Labioplastik, Vaskularität der inneren Schamlippen, Kaltlichtbeleuchtung, innere Schamlippen, Verkleinerung der inneren Schamlippen

$\begin{array}{lr}\text { received } & 31.3 .2018 \\ \text { revised } & 16.5 .2018 \\ \text { accepted } & 21.6 .2018\end{array}$

Bibliography

DOI https://doi.org/10.1055/a-0647-2404

Geburtsh Frauenheilk 2018; 78: 775-784 @ Georg Thieme

Verlag KG Stuttgart · New York I ISSN 0016-5751

\section{Correspondence}

Ozan Dogan, MD

Department of Obstetrics and Gynecology, Health Sciences University, Sisli Hamidiye Etfal Research and Training Hospital Binbasi Refikbey sk, No: 9/5 Sisli, 0341000 Istanbul, Turkey ozandogan02@hotmail.com

\section{ABSTRACT}

Objective Aim of the study was to assess the feasibility of a novel technique to determine the vascularity of labia minora prior to labiaplasty.

Methods A cold light source employed in laparoscopic procedures was used to illuminate the outer surface of the labia minora as described in this prospective descriptive study.

Results Of the patients, $46.1 \%(n=41)$ had upper third prominence, $36 \%(n=32)$ had middle third prominence, and $18 \%(n=16)$ had lower third prominence according to the Banwell classification of morphologies. Right labia minora width was $0-2 \mathrm{~cm}$ in $51.7 \%(n=46), 2-4 \mathrm{~cm}$ in $47.2 \%$ $(n=42)$ and $>4 \mathrm{~cm}$ in $1.1 \%(n=1)$ of cases. Left labia minora width was $0-2 \mathrm{~cm}$ in $52.8 \%(n=47), 2-4 \mathrm{~cm}$ in $41.6 \%(n=37)$ and $>4 \mathrm{~cm}$ in $5.6 \%(n=5)$ of cases. The incidence of Anterior 2 and Posterior 1 vessels in the different morphologies were statistically significantly different $(p=0.007, p=0.018)$. The Anterior 2 vessel was higher in the lower morphology group whereas the Posterior 1 vessel was higher in the upper morphology group. A central vessel was observed in $93.3 \%$ $(n=83)$ of patients in the left labium minus and the right labium minus. The incidence of the Posterior 1 vessel was significantly higher in the left labium minus than in the right labium minus $(p=0.021)$.

Discussion This novel technique to assess labial vascularity using a cold light source could be very useful to reduce dehiscence by avoiding excessive resection of highly vascularized tissue. Most units can easily access a cold light source, which can be used to assess labial vascularity prior to labiaplasty.

\section{ZUSAMMENFASSUNG}

Zielsetzung Ziel dieser Studie war es, die Durchführbarkeit einer neuartigen Technik zur Bestimmung der Vaskularität der inneren Schamlippen vor der Labioplastik zu evaluieren.

Methoden Die Kaltlichtbeleuchtungsquelle, die bei einer Laparoskopie eingesetzt wird, wurde zur Beleuchtung der äußeren Oberfläche der inneren Schamlippen verwendet, wie hier in dieser prospektiven Studie beschrieben.

Ergebnisse Nach der Banwell-Klassifikation der Schamlippenmorphologie hatten 46,1\% $(n=41)$ der untersuchten Pa- 
tientinnen eine Auswölbung im oberen Drittel, 36\% ( $n=32)$ eine Auswölbung im mittleren Drittel, und 18\% ( $n=16)$ eine Auswölbung im unteren Drittel. Die Breite der rechten inneren Schamlippe betrug $0-2 \mathrm{~cm}$ in $51,7 \%(\mathrm{n}=46), 2-4 \mathrm{~cm}$ in $47,2 \%(n=42)$ und $>4 \mathrm{~cm}$ in $1,1 \%(n=1)$ der Fälle. Die Breite der linken inneren Schamlippe betrug $0-2 \mathrm{~cm}$ in $52,8 \%$ ( $\mathrm{n}=47), 2-4 \mathrm{~cm}$ in $41,6 \%(\mathrm{n}=37)$ und $>4 \mathrm{~cm}$ in $5,6 \%(\mathrm{n}=5)$ der Fälle. Es gab einen statistisch signifikanten Unterschied in der Häufigkeit von Anterior-2- und Posterior-1-Gefäßen zwischen den verschiedenen Morphologien ( $p=0,007$; $p=0,018$ ). Anterior-2-Gefäße traten häufiger in der Gruppe mit unterer Auswölbung auf, wohingegen Posterior-1-Gefäße öfters in der Gruppe mit oberer Auswölbung auftraten. Ein zentrales Gefäß wurde bei 93,3\% ( $n=83)$ der Patientinnen sowohl in der linken wie in der rechten inneren Schamlippe identifiziert. Ein Posterior-1-Gefäß wurde häufiger in der linken als in der rechten inneren Schamlippe entdeckt $(p=0.021)$.

Diskussion Dieses neuartige Verfahren zur Bestimmung der Vaskularität der inneren Schamlippen mithilfe einer Kaltlichtbeleuchtungsquelle könnte sehr nützlich bei der Reduzierung der Wunddehiszenz sein, weil sich damit eine exzessive Gewebsentfernung vermieden ließe. In den meisten Krankenhäusern ist eine Kaltlichtbeleuchtungsquelle vorhanden, die zur Darstellung der Vaskularität der inneren Schamlippen vor der Labioplastik benutzt werden kann.

\section{Introduction}

Labiaplasty is increasingly being performed and is estimated to account for more than $90 \%$ of esthetic female genital surgery procedures [1]. According to statistical data from the United States, 8,745 patients underwent labiaplasty in 2015 . It also has been observed that $58.8 \%$ of patients who undergo such surgery are under 35 years of age. It is worth noting that there was a $14 \%$ increase in the number of labiaplasty procedures between 2014 and 2015 [2]. Women who want labiaplasty for esthetic purposes believe that the appearance of their labia minora is not normal. However, what constitutes a normal appearance for the labia minora is still being discussed as it varies from culture to culture $[3,4]$.

Sometimes labiaplasty is performed for functional reasons, such as entry dyspareunia or the need to push aside the labia minora during manual intercourse. Another cited reason is a feeling of discomfort when wearing clothing and during exercise, which goes beyond esthetic concerns [5]. Edge resection, wedge resection, de-epithelialization, Z-plasty, W-plasty, and laser labiaplasty are the most commonly used labia minora reduction techniques. Labiaplasty has high rates of patient satisfaction, and each technique has its advantages and disadvantages [6, 7].

The surgery is planned based on patient expectations, the surgeon's experience, the appropriateness of the technique, wound tension, and other surgical requirements. The success of surgery is multifactorial. Tissue oxygenation is important for wound healing [8]. Complications can include wound dehiscence, hematoma, irregular edge formation, scarring, over-resection, fenestration, and shortened vaginal introitus [6]. With dehiscence, the most common complication of labiaplasty, tissue vascularization is disturbed. In this study, we aimed to investigate the vascularity of the labium minus as vascularization can be a guide when choosing the appropriate surgical technique. Knowledge of the vascularity of the labium minus is limited as there are only a small number of cadaver dissection studies $[9,10]$. The literature offers no practical method for assessing the vascularity of the labium minus. Using a cold light source to determine the vascularity of the labium minus could allow the surgeon to adapt the surgical technique and plan the procedure accordingly, while also taking additional factors into account.

\section{Materials and Methods}

\section{Study design and patient population}

This prospective descriptive study included all patients who underwent any gynecological intervention in two tertiary centers between September 2017 and January 2018. Patients who were pregnant, who had given birth within three months, who had pelvic organ prolapse (POP) $\geq$ grade 2 , who underwent surgery to repair POP, who were scheduled to undergo surgery for vulvar cancer or other gynecologic cancers, who had vulvar varicosities, and who had previously undergone esthetic genital surgery were excluded from the study. One hundred patients who did fulfill these criteria agreed to participate and were included in the study. Before patients were taken to the operating room, they were interviewed to obtain descriptive characteristics, such as age, parity, BMI, marital status, menopausal status, type of delivery, previous episiotomy, occupation, income status, comorbidities, and drug use. The Banwell classification classifies labia minora into the following morphologies according to the distance from the most lateral prominence of the labium minus to the vaginal introitus: type 1 = upper third prominence, type 2 = middle third prominence, and type 3 = lower third prominence [11]. The labia minora of our patients were classified using this morphological categorization. The width of the labium minus was measured from a vertical line drawn to the base of the labium minus from the widest lateral prominence. According to the Motakef classification, labial protrusion is classified as class $1(0-2 \mathrm{~cm})$, class $2(2-4 \mathrm{~cm})$, and class 3 $(>4 \mathrm{~cm})$ [12].

Because labia minora width was very short in three women $(0.5,0.4$, and $0.4 \mathrm{~cm})$, vascularity was not assessed in these patients, and they were excluded from the study. Women with asymmetric labia minora were classified as asymmetric. In three patients, the left and right labia minora had different morphological classifications. Because we planned our analysis based on this classification of morphologies, these patients were also excluded from the study. No significant vascularity was identified in five patients and only delicate abnormal anastomoses were observed. Analysis was therefore not carried out in these women. The remaining 89 patients were included in the study. 


\section{Application of the new technique}

Examinations were carried out prior to surgery, before dyeing and covering. Patients were examined under regional/general or local anesthetic or without anesthesia, with all patients in the lithotomy position. The characteristics of the external genitalia, labial symmetry/asymmetry, morphological features, color, edge properties, and labia minora widths were recorded in the patient chart. The lights in the operating room were turned off, and the labium minus was slightly opened at its most prominent point using a non-serrated instrument or by hand. The cold light source used in laparoscopic procedures was brought close to the outer surface of the labia minora ( $\triangleright$ Fig. 1 ).

In 2015 Georgiou et al. created a vascularity map of the labium minus [9]. Using the vascularity and labeling of their map, in our study labial vascularity was assessed from the inner surface of the labium minus and the findings recorded. The vessel running along the entire edge and the vessel running along the entire base were defined but not identified. Vessels that were rare and did not meet the predefined definitions were recorded as "other". Thin anastomoses were seen in some patients. After each operation, the light source was sterilized by autoclave. Vascularity was marked on the right and the left side for each labium minus. Measurements were carried out by two physicians with at least 10 years' experience in gynecological and obstetric care.

\section{Ethical approval}

The study was approved by the Ethics Committee of Duzce University Faculty of Medicine (Decision No: 2017/123). Informed consent form was obtained from all patients who agreed to participate in the study.

\section{Statistical analysis}

The Statistical Package for the Social Sciences (SPSS) 15.0 for Windows was used for statistical analysis. Numerical variables are presented as mean \pm standard deviation. The Kruskal-Wallis test was used to compare numerical variables in multiple independent groups if they were not normally distributed. The $x^{2}$ test was used to compare ratios in groups. The Monte Carlo simulation was applied if ratios were not normally distributed, and the McNemar test was used to compare ratios in dependent groups. A p-value of $<0.05$ was considered statistically significant.

\section{Results}

\section{Demographic data}

The general patient characteristics and morphology groups are summarized in Table 1 . Mean age of the patients was $34.3 \pm 8.6$ years, and mean body mass index (BMI) was $24.0 \pm 3.5$.

\section{Morphologic features}

The patients were divided into three groups according to labia minora morphology. Of the participants, $46.1 \%(n=41)$ had upper third prominence, $36 \%(n=32)$ had middle third prominence, and $18 \%(n=16)$ had lower third prominence. The mean width of the labium minus was measured as $2.13 \pm 0.77 \mathrm{~cm}$ (mean \pm SD; min-max, $1-5 \mathrm{~cm}$ ) on the right side and $2.23 \pm 0.86 \mathrm{~cm}$
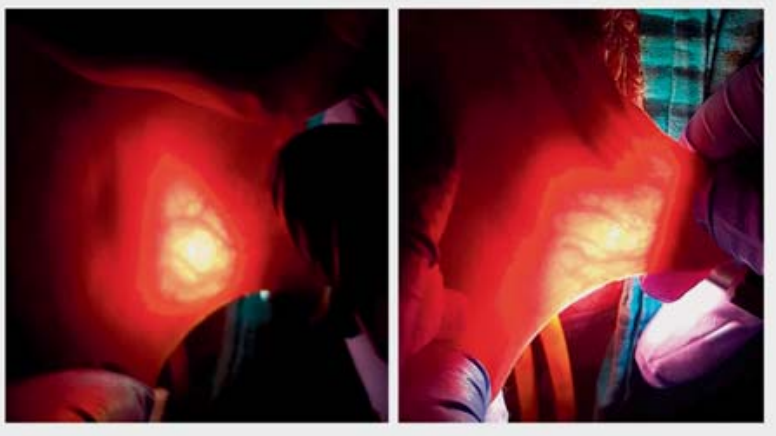

- Fig. 1 Photographs showing the vascularity of labia minora using cold light illumination.

(mean \pm SD; min-max, $1.1-7.6 \mathrm{~cm}$ ) on the left side. Labia were also classified based on these measurements.

Right labia minora width was $0-2 \mathrm{~cm}$ in $51.7 \%$ ( $\mathrm{n}=46), 2-4 \mathrm{~cm}$ in $47.2 \%(n=42)$ and $>4 \mathrm{~cm}$ in $1.1 \%(n=1)$. Left labia minora width was $0-2 \mathrm{~cm}$ in $52.8 \%(\mathrm{n}=47), 2-4 \mathrm{~cm}$ in $41.6 \%(\mathrm{n}=37)$ and $>4 \mathrm{~cm}$ in $5.6 \%(n=5)$. A statistically significant difference was found between morphology groups with regard to labial fold, soft tissue color around the labium minus, and width of the right labium minus ( $p=0.003, p=0.036$, and $p=0.017$ ). The labia minora fold was statistically significantly marked in the lower morphology group compared to the other morphology groups $(p=0.001)$. The soft tissue color around the labia minora was statistically significantly higher in the upper morphology group than in the lower morphology group $(p=0.050)$. The percentage of labia minora widths of $2-4 \mathrm{~cm}$ was higher in the upper morphology group compared to the middle morphology group $(p=0.012)$.

No statistically significant difference with regard to any vascular structure of the labium minus was found between symmetrical ( $n=56,62.9 \%)$ and asymmetrical $(n=33,37 \%)$ patients $(p=0.07)$. The rate of asymmetry was statistically significantly higher in women who had had an episiotomy than in women without prior episiotomy $(p<0.001)$. There was no statistically significant difference between the vascular structures of the right and left labia minora in the asymmetric group $(p=0.05)$.

\section{Distribution of vascularity of right and left labia minora}

Arterial distribution on the right and left sides of the labia minora is summarized in $>$ Table 2 and shown in > Figs. 2 to $\mathbf{5}$. The central vessel was observed on the right side in $93.3 \%(n=83)$ of cases. The incidence differed significantly between morphology groups $(p=0.003)$. While the central vessel was observed in all labia minora with an upper morphology $(n=41)$, it was observed in $75 \%$ of labia minora with a lower morphology. The incidence of Anterior 2 and Posterior 1 vessels differed significantly between morphology groups $(p=0.007, p=0.018)$. The incidence of Anterior 2 vessels was higher in the lower morphology group whereas the incidence of Posterior 1 vessels was higher in the upper morphology group ( $\triangleright$ Table 2 ). The central vessel was observed in 
- Table 1 General characteristics of patients according to labia minora morphology.

\begin{tabular}{|c|c|c|c|c|c|c|c|c|c|}
\hline & \multicolumn{9}{|c|}{ Morphology } \\
\hline & \multicolumn{2}{|c|}{ Total } & \multicolumn{2}{|c|}{$\begin{array}{l}\text { Upper third } \\
\text { prominence } \\
n=41(46.1 \%)\end{array}$} & \multicolumn{2}{|c|}{$\begin{array}{l}\text { Middle third } \\
\text { prominence } \\
\mathrm{n}=32(36 \%)\end{array}$} & \multicolumn{2}{|c|}{$\begin{array}{l}\text { Lower third } \\
\text { prominence } \\
n=16(18 \%)\end{array}$} & $\mathbf{p}$ \\
\hline Age (years) & \multicolumn{2}{|c|}{$34.3 \pm 8.6$} & \multicolumn{2}{|c|}{$34.9 \pm 9.2$} & \multicolumn{2}{|c|}{$33.9 \pm 8.2$} & \multicolumn{2}{|c|}{$33.8 \pm 8.4$} & 0.931 \\
\hline \multirow[t]{2}{*}{ BMI } & \multicolumn{2}{|c|}{$24.0 \pm 3.5$} & \multicolumn{2}{|c|}{$24.0 \pm 3.3$} & \multicolumn{2}{|c|}{$24.1 \pm 3.9$} & \multicolumn{2}{|c|}{$23.6 \pm 3.5$} & 0.966 \\
\hline & $\mathrm{N}$ & $\%$ & $\mathrm{~N}$ & $\%$ & $\mathrm{n}$ & $\%$ & $n$ & $\%$ & \\
\hline \multicolumn{10}{|l|}{ Marital status } \\
\hline - single & 17 & 19.1 & 7 & 17.1 & 6 & 18.8 & 4 & 25.0 & 0.727 \\
\hline - married & 72 & 80.9 & 34 & 82.9 & 26 & 81.3 & 12 & 75.0 & \\
\hline Nulliparous & 55 & 61.8 & 28 & 68.3 & 21 & 65.6 & 6 & 37.5 & 0.085 \\
\hline \multicolumn{10}{|l|}{ Type of birth } \\
\hline - none & 12 & 13.5 & 2 & 4.9 & 6 & 18.8 & 4 & 25.0 & 0.141 \\
\hline - vaginal & 52 & 58.4 & 24 & 58.5 & 19 & 59.4 & 9 & 56.3 & \\
\hline - cesarean & 25 & 28.1 & 15 & 36.6 & 7 & 21.9 & 3 & 18.8 & \\
\hline \multicolumn{10}{|l|}{ Menopause } \\
\hline - menopause & 8 & 9.0 & 4 & 9.8 & 1 & 3.1 & 3 & 18.8 & 0.134 \\
\hline \multicolumn{10}{|l|}{ Episiotomy } \\
\hline - yes & 47 & 52.8 & 23 & 56.1 & 17 & 53.1 & 7 & 43.8 & 0.703 \\
\hline \multicolumn{10}{|l|}{ Income } \\
\hline - minimum wage or less & 11 & 12.6 & 4 & 10.0 & 5 & 15.6 & 2 & 13.3 & 0.726 \\
\hline . $1500-2500 \mathrm{TL}$ & 24 & 27.6 & 15 & 37.5 & 6 & 18.8 & 3 & 20.0 & \\
\hline - 2500-5000 TL & 33 & 37.9 & 12 & 30.0 & 15 & 46.9 & 6 & 40.0 & \\
\hline - 5000-10000 TL & 14 & 16.1 & 7 & 17.5 & 4 & 12.5 & 3 & 20.0 & \\
\hline - 10000 TL or more & 5 & 5.7 & 2 & 5.0 & 2 & 6.3 & 1 & 6.7 & \\
\hline \multicolumn{10}{|l|}{ Smoking } \\
\hline " no & 57 & 64.8 & 29 & 70.7 & 19 & 59.4 & 9 & 60.0 & 0.757 \\
\hline - fewer than 10 cigarettes per day & 18 & 20.5 & 6 & 14.6 & 8 & 25.0 & 4 & 26.7 & \\
\hline - more than 10 cigarettes per day & 13 & 14.8 & 6 & 14.6 & 5 & 15.6 & 2 & 13.3 & \\
\hline \multicolumn{10}{|l|}{ Labial fold } \\
\hline - straight & 13 & 14.6 & 8 & 19.5 & 5 & 15.6 & 0 & 0.0 & 0.003 \\
\hline " moderate & 62 & 69.7 & 30 & 73.2 & 24 & 75.0 & 8 & 50.0 & \\
\hline - prominent & 14 & 15.7 & 3 & 7.3 & 3 & 9.4 & 8 & 50.0 & \\
\hline \multicolumn{10}{|l|}{ Soft tissue color around labium minus } \\
\hline - same & 78 & 87.6 & 32 & 78.0 & 30 & 93.8 & 16 & 100 & 0.036 \\
\hline - different & 11 & 12.4 & 9 & 22.0 & 2 & 6.3 & 0 & 0.0 & \\
\hline Labium minus classification & & & & & & & & & \\
\hline - asymmetric & 28 & 31.5 & 10 & 24.4 & 11 & 34.4 & 7 & 43.8 & 0.209 \\
\hline - symmetric & 61 & 68.5 & 31 & 75.6 & 21 & 65.6 & 9 & 56.3 & \\
\hline Right labium minus width & & & & & & & & & \\
\hline . $0-2 \mathrm{~cm}$ & 46 & 51.7 & 14 & 34.1 & 21 & 65.6 & 11 & 68.8 & 0.017 \\
\hline - $2-4 \mathrm{~cm}$ & 42 & 47.2 & 26 & 63.4 & 11 & 34.4 & 5 & 31.3 & \\
\hline.$>4 \mathrm{~cm}$ & 1 & 1.1 & 1 & 2.4 & 0 & 0.0 & 0 & 0.0 & \\
\hline Left labium minus width & & & & & & & & & \\
\hline . $0-2 \mathrm{~cm}$ & 47 & 52.8 & 16 & 39.0 & 20 & 62.5 & 11 & 68.8 & 0.069 \\
\hline . $2-4 \mathrm{~cm}$ & 37 & 41.6 & 21 & 51.2 & 12 & 37.5 & 4 & 25.0 & \\
\hline.$>4 \mathrm{~cm}$ & 5 & 5.6 & 4 & 9.8 & 0 & 0.0 & 1 & 6.3 & \\
\hline
\end{tabular}

A p-value of $<0.05$ was considered statistically significant. 
- Table 2 Distribution of vascularity of right and left labia minora according to labia minora morphologies.

\begin{tabular}{|c|c|c|c|c|c|c|c|c|c|}
\hline & \multicolumn{9}{|c|}{ Morphology } \\
\hline & \multicolumn{2}{|c|}{ Total } & \multicolumn{2}{|c|}{ Upper } & \multicolumn{2}{|c|}{ Middle } & \multicolumn{2}{|c|}{ Lower } & \multirow[b]{2}{*}{$\mathbf{p}$} \\
\hline & $\mathbf{n}$ & $\%$ & $\mathbf{n}$ & $\%$ & $\mathbf{N}$ & $\%$ & $\mathbf{n}$ & $\%$ & \\
\hline \multicolumn{10}{|l|}{ Right } \\
\hline - Central vessel & 83 & 93.3 & 41 & 100 & 30 & 93.8 & 12 & 75.0 & 0.003 \\
\hline - Anterior 1 & 56 & 62.9 & 23 & 56.1 & 21 & 65.6 & 12 & 75.0 & 0.383 \\
\hline - Anterior 2 & 4 & 4.5 & 0 & 0.0 & 1 & 3.1 & 3 & 18.8 & 0.007 \\
\hline - Posterior 1 & 50 & 56.2 & 29 & 70.7 & 16 & 50.0 & 5 & 31.3 & 0.018 \\
\hline - Posterior 2 & 2 & 2.2 & 1 & 2.4 & 1 & 3.1 & 0 & 0.0 & 1.000 \\
\hline - Base artery & 4 & 4.5 & 1 & 2.4 & 3 & 9.4 & 0 & 0.0 & 0.395 \\
\hline - Edge artery & 6 & 6.7 & 3 & 7.3 & 2 & 6.3 & 1 & 6.3 & 1.000 \\
\hline \multicolumn{10}{|l|}{ Left } \\
\hline - Central vessel & 83 & 93.3 & 39 & 95.1 & 29 & 90.6 & 15 & 93.8 & 0.852 \\
\hline - Anterior 1 & 52 & 58.4 & 21 & 51.2 & 19 & 59.4 & 12 & 75.0 & 0.260 \\
\hline - Anterior 2 & 2 & 2.2 & 0 & 0.0 & 1 & 3.1 & 1 & 6.3 & 0.288 \\
\hline - Posterior 1 & 58 & 65.2 & 30 & 73.2 & 21 & 65.6 & 7 & 43.8 & 0.111 \\
\hline - Posterior 2 & 5 & 5.6 & 2 & 4.9 & 3 & 9.4 & 0 & 0.0 & 0.583 \\
\hline - Base artery & 7 & 7.9 & 3 & 7.3 & 4 & 12.5 & 0 & 0.0 & 0.340 \\
\hline - Edge artery & 7 & 7.9 & 4 & 9.8 & 2 & 6.3 & 1 & 6.3 & 0.876 \\
\hline
\end{tabular}

- Table 3 Vascularity of right and left labia minora according to labia minora width.

\begin{tabular}{|c|c|c|c|c|c|c|c|c|c|c|c|c|c|c|}
\hline & \multicolumn{6}{|c|}{ Right } & & \multicolumn{6}{|c|}{ Left } & \\
\hline & \multicolumn{6}{|c|}{ Labia minora width } & & \multicolumn{6}{|c|}{ Labia minora width } & \\
\hline & \multicolumn{2}{|c|}{$0-2$} & \multicolumn{2}{|c|}{$2-4$} & \multicolumn{2}{|c|}{$>4$} & \multirow[b]{2}{*}{$\mathbf{p}$} & \multicolumn{2}{|c|}{$0-2$} & \multicolumn{2}{|c|}{$2-4$} & \multicolumn{2}{|c|}{$>4$} & \multirow[b]{2}{*}{$\mathbf{p}$} \\
\hline & n & $\%$ & $\mathbf{n}$ & $\%$ & $\mathbf{n}$ & $\%$ & & $\mathbf{n}$ & $\%$ & $n$ & $\%$ & $\mathbf{n}$ & $\%$ & \\
\hline Central vessel & 43 & 93.5 & 39 & 92.9 & 1 & 100 & 1.000 & 42 & 89.4 & 36 & 97.3 & 5 & 100 & 0.459 \\
\hline Anterior 1 & 29 & 63.0 & 27 & 64.3 & 0 & 0.0 & 0.542 & 26 & 55.3 & 23 & 62.2 & 3 & 60.0 & 0.874 \\
\hline Anterior 2 & 3 & 6.5 & 1 & 2.4 & 0 & 0.0 & 0.642 & 2 & 4.3 & 0 & 0.0 & 0 & 0.0 & 0.561 \\
\hline Posterior 1 & 23 & 50.0 & 26 & 61.9 & 1 & 100 & 0.340 & 28 & 59.6 & 26 & 70.3 & 4 & 80.0 & 0.539 \\
\hline Posterior 2 & 1 & 2.2 & 1 & 2.4 & 0 & 0.0 & 1.000 & 1 & 2.1 & 3 & 8.1 & 1 & 20.0 & 0.145 \\
\hline Base artery & 3 & 6.5 & 1 & 2.4 & 0 & 0.0 & 0.642 & 7 & 14.9 & 0 & 0.0 & 0 & 0.0 & 0.027 \\
\hline Edge artery & 1 & 2.2 & 5 & 11.9 & 0 & 0.0 & 0.158 & 3 & 6.4 & 4 & 10.8 & 0 & 0.0 & 0.793 \\
\hline
\end{tabular}

A p-value of $<0.05$ was considered statistically significant.

93.3\% $(n=83)$ of patients in the left labium minus and the right labium minus (• Fig. 2 ).

When the vascularity rates of the left and right labia minora were compared, the differences were not statistically significant except for Posterior 1 vessels. The incidence of Posterior 1 vessels was significantly higher in the left labium minus than in the right labium minus ( $p=0.021)$ ( $\triangleright$ Fig. 1$)$. This difference was more significant in the middle morphology group than in the other morphology groups $(p=0.025)$.
When all vascular structures of the labia minora were evaluated, a statistically significant difference was found in the incidence of central and posterior vessels according to morphology $(p=0.037, p=0.003)$. Independent subgroup analysis showed that this difference was present for the upper and lower morphologies; the incidence of central and posterior vessels was significantly higher in labia minora with an upper morphology than in labia minora with a lower morphology $(p=0.005, p=0.015)$. 


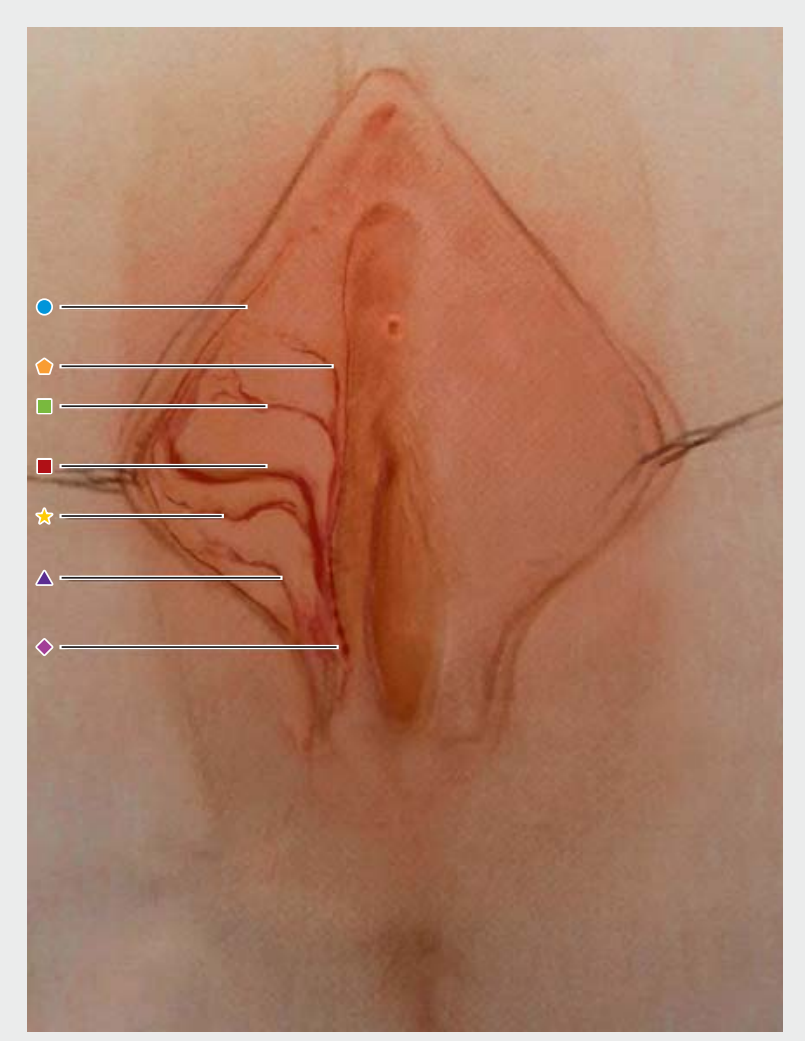

Labia minora - middle morphology, right side

- Central: $93.8 \%(n=30)$

- Anterior 2: 3.1\% $(n=1)$

- Posterior 2: $3.1 \%(n=1)$

- Edge: $6.3 \%(n=2)$

n Anterior 1: 65.6\% $(n=21)$

Posterior 1: $50 \%(n=16)$

- Base: $9.4 \%(n=3)$

Other: $12.5 \%(n=4)$

Labia minora - middle morphology, left side

- Central: 90.6\% ( $n=29)$

- Anterior 2: 3.1\% $(n=1)$

- Posterior 2: $9.4 \%(n=3)$

- Edge: $6.3 \%(n=2)$

- Anterior 1: 59.4\% $(n=19)$

Posterior 1: 65.6\% $(n=21)$

- Base: $12.5 \%(n=4)$

Other: $9.4 \%(n=3)$

- Fig. 2 Percentage of vessels detected in labia minora with middle morphology.

There was no statistically significant difference between right and left labium minus width groups $(p=0.131)$ or in right-sided vascular structures in the right labium minus width groups. There was a statistically significantly difference in the incidence of the base artery in the left vascular structures of left labia minora in the $0-2 \mathrm{~cm}$ group $(\mathrm{p}=0.027)(\triangleright$ Table 3$)$.

There was a statistically significant difference in the incidence of right central vessels and posterior vessels and the incidence of left central vessels and posterior vessels in patients who smoked $(p=0.047, p=0.020, p=0.016$ and $p=0.001)$. On the right side, the incidence of the central vessels was lower in patients who smoked more than ten cigarettes a day, and the incidence of the posterior vessels was lower in those who smoked fewer than ten cigarettes a day. On the left side, the incidence of the central ves-

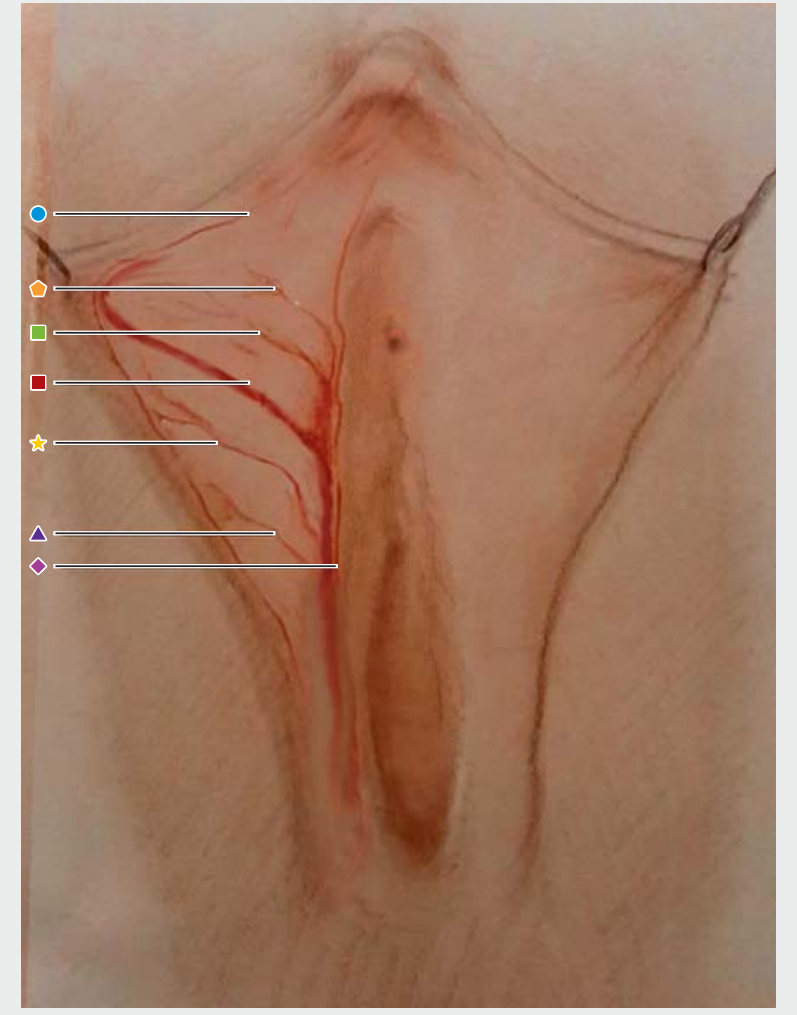

Labia minora - upper morphology, right side

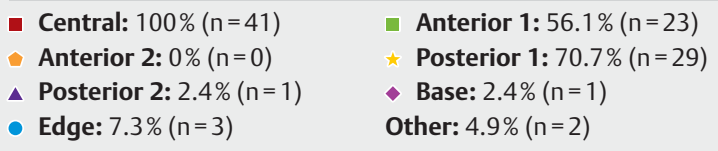

- Central: $100 \%(n=41)$

- Anterior 2: 0\% $(n=0)$

- Posterior 2: $2.4 \%(n=1)$

- Edge: $7.3 \%(n=3)$

- Anterior 1: $56.1 \%(n=23)$

Posterior 1: $70.7 \%(n=29)$

- Base: $2.4 \%(n=1)$

Other: $4.9 \%(n=2)$

\section{Labia minora - upper morphology, left side}

- Central: $95.1 \%(n=39)$

- Anterior 2: 0\% $(n=0)$

- Anterior 1: $51.2 \%(n=21)$

- Posterior 2: $4.9 \%(n=2)$

Posterior 1: $73 \%(n=30)$

- Edge: $9.8 \%(n=4)$

- Base: $7.3 \%(n=3)$

Other: $2.4 \%(n=1)$

- Fig. 3 Percentage of vessels detected in labia minora with upper morphology. sels was lower in patients who smoked more than ten cigarettes a day, and the incidence of the posterior vessels was lower in patients who smoked fewer than ten cigarettes a day.

Vascularity detection took a mean of $1.3 \pm 0.9$ minutes (mean \pm SD) for each labium minus. Detection took longer in the first few patients evaluated with this method. However, the learning curve rose rapidly after the first five patients. There was no significant difference in the duration of vascularity detection between those who had delivered with or and those who had delivered without anesthesia $(n=62$ and $n=27$, respectively; $p=0.208)$. 


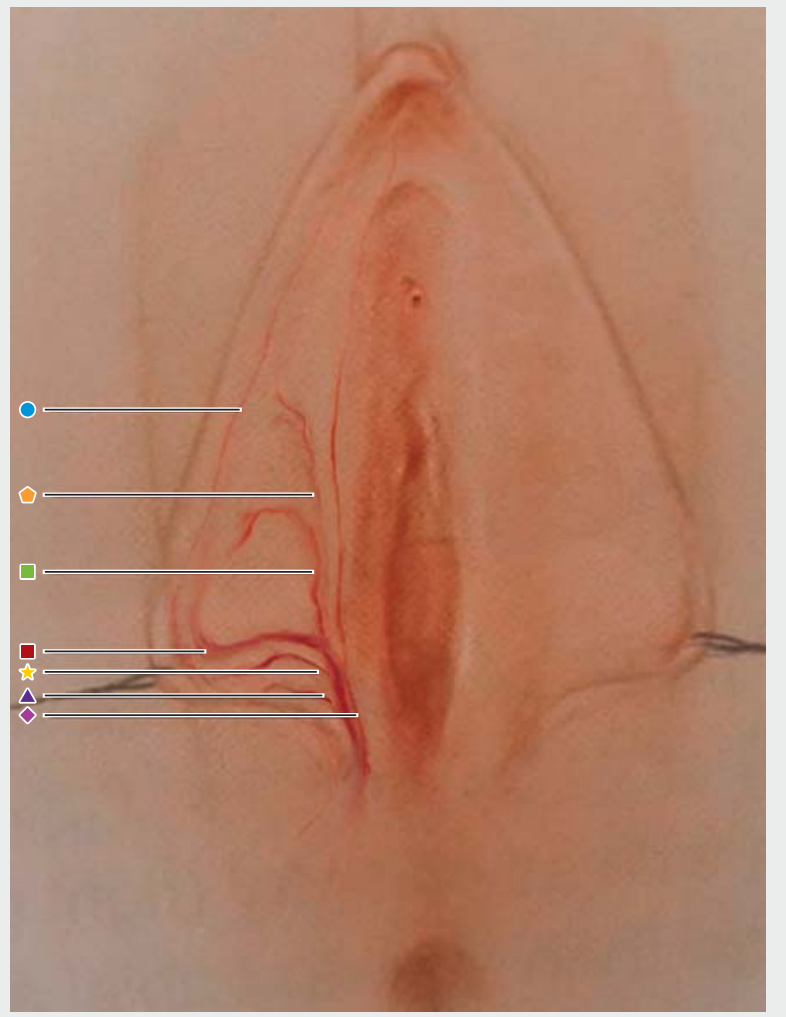

Labia minora - lower morphology, right side

- Central: $75 \%(n=12)$

Anterior 2: $18.8 \%(n=3)$

- Posterior 2: $0 \%(n=0)$

Edge: $6.3 \%(n=1)$

Anterior 1: $75 \%(n=12)$

Posterior 1: $31.3 \%(n=5)$

- Base: $0 \%(n=0)$

Other: $18.8 \%(n=3)$

Labia minora - lower morphology, left side

- Central: $93.8 \%(n=15)$

- Anterior 2: $6.3 \%(n=1)$

A Posterior 2: $0 \%(n=0)$

- Edge: $6.3 \%(n=1)$

- Anterior 1: $75 \%(n=12)$

Posterior 1: $43.8 \%(n=7)$

- Base: $0 \%(n=0)$

Other: $6.3 \%(n=1)$

- Fig. 4 Percentage of vessels detected in labia minora with lower morphology.

\section{Discussion}

The multi-stratified non-keratinized epithelium of the labium minus contains sebaceous and sweat glands [13]. Due to its mucocutaneous fine structure and hairless skin, vasculature under the skin can be easily detected with a light source. We planned this study using the light source employed in laparoscopic abdominal procedures. We had been inspired by the fact that vessels could be clearly detected with this light source, despite the thick subcutaneous tissue of the abdominal wall.

One of the limitations of the study is the low number of patients, especially patients with labial hypertrophy. Moreover, no patients whose right and left labia minora were morphologically asymmetric were included in our study. Three patients with asym- metric labia minora diameters were assessed and excluded from the study because they did not meet the inclusion criteria, which is another limitation of the study. There were only six patients with a labium minus width of $4 \mathrm{~cm}$ or more in our study population. The reason for this is that our study population consisted of patients who planned to undergo intervention for other gynecological reasons, not women who came to hospital for esthetic genital surgery.

In a study carried out in 1985, dissection revealed that the arteries of the labium minus were accompanied by veins of the labium minus [10]. In our study, vessels were traced using the light source, until the most proximal part where the detected vessel continued to thicken. Pressure was applied at the last visible point, and these vessels were then recorded as arteries if the color faded. However, it is not possible to precisely distinguish between arteries and veins using this method, as interventional approaches, such as angiography or dissection, were not performed as were done in other studies.

This technique is easy to use. This type of cold light source is available in all units which carry out laparoscopic surgery. The technique is easy to use in any patient examined in the lithotomy position. Patients do not feel pain as there is no need to apply too much tension. In our study, detection was easy, both with or without anesthesia, and irrespective of the time used for detection. In non-anesthetized patients, it may be more appropriate to open the most lateral side of the labium minus manually rather than with an instrument.

The cadaver study published by Georgiou et al. in 2015 was the first to describe the vasculature of the labium minus in detail. In their study, they created an arterial map of the labium minus of 11 cadavers, using contrast-enhanced computed tomography and rotational angiography. Their study identified a dominant central artery which they named the " $C$ " artery, two posterior arteries named "P1" and "P2", and one small anterior artery named "A". A connection between the anterior system of the external pudendal artery and the posterior system of the internal pudendal artery was also confirmed in their study. We have used the same terminology for the vessels detected in our study [9].

Rouzier et al. performed labiaplasty in 163 patients and accepted only patients with a labium minus width of $4 \mathrm{~cm}$ or more. All patients underwent only posterior wedge resection with anterior flap. Wound dehiscence occurred only in $7 \%$ of patients [14]. In a labiaplasty study involving 21 patients performed by Munhoz et al. in 2006, all patients underwent posterior wedge resection. Distal flap necrosis and wound dehiscence occurred in $14.2 \%$ of patients [15]. In a retrospective study by Ouar et al. which compared edge and wedge resection, wound dehiscence was the most common complication with a rate of $13 \%$. They reported that the tendency to wound dehiscence was greater following wedge resection than after edge resection [16].

When wedge resection is used, there is no change in color, scar formation is less pronounced, and the results are more esthetically pleasing since the natural edge of the labium minus is preserved. However, wound dehiscence rates are higher compared to other techniques [14-16]. It has been reported that the posterior arterial network is larger, and blood flow is greater with posterior wedge resection, because of the presence of the P1 and P2 


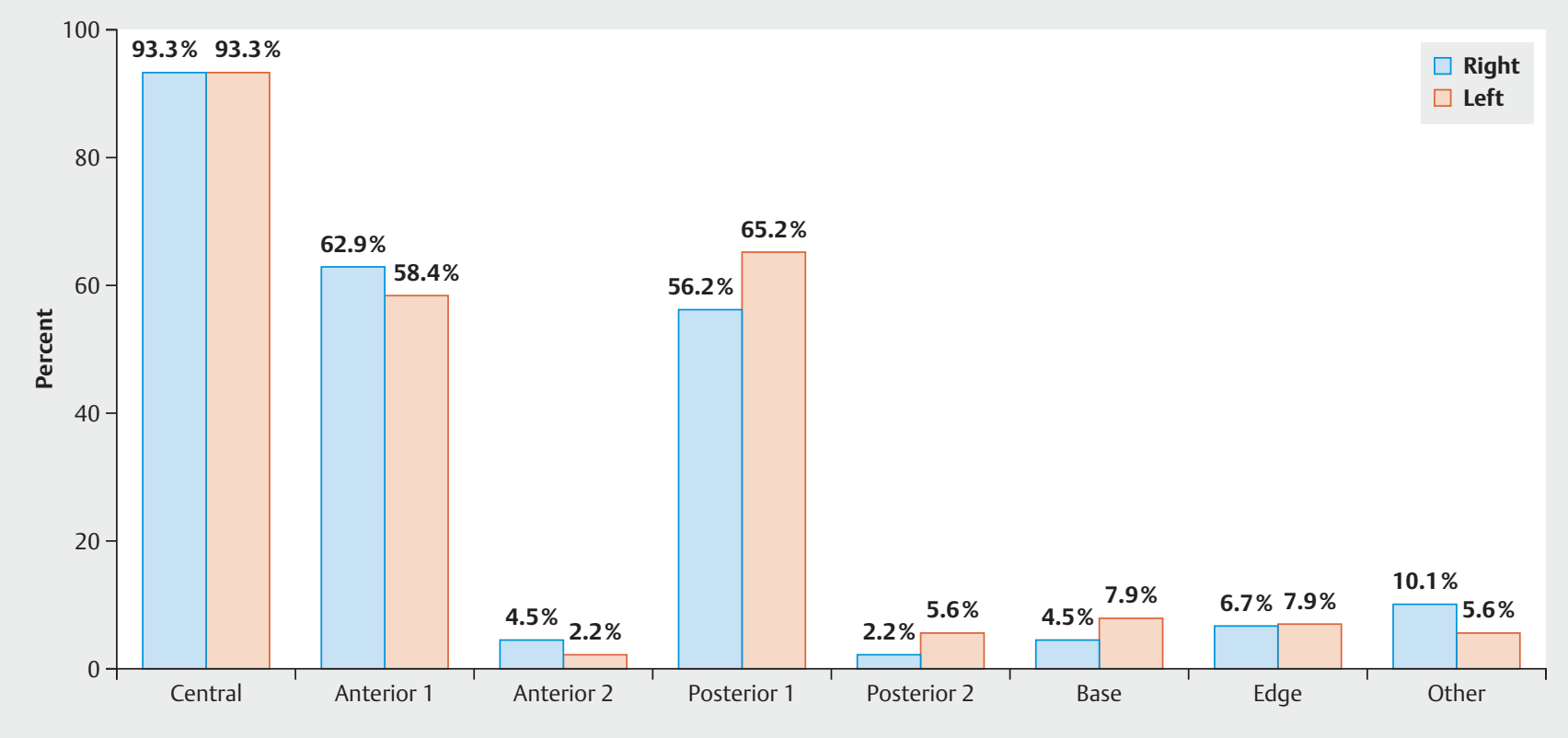

- Fig. 5 Incidence of vessels observed in the right and left labia minora.

vessels below the middle line of the labium minus described by Georgiou et al. The high rates of wound dehiscence associated with this technique have been attributed to extensive resection of the arterial network, suggesting that the vasculature of the remaining anterior flap is not sufficient to provide an adequate supply of blood to the remaining tissue [9]. Tissue oxygenation is one of the factors that affect wound healing, but tissue oxygenation requires adequate vascularization. A practical method has not yet been identified to determine the vasculature of the tissue resected during labiaplasty. We think that complication rates could be reduced by evaluating the vascularity of the tissue to be resected and of the tissue that will not be resected. In addition to the suture technique, the surgeon's experience, the patient's characteristics, and excessive tension on the wound, the main cause of such complications as wound dehiscence and fenestration is the reduction of blood supply following the resection of areas of higher vascularity. These complication rates could be reduced by assessing tissue vascularity before choosing the appropriate technique.

In the study by Bucknor et al., they reported that cigarette use was the main cause of postoperative sequelae and higher complication rates in patients undergoing labiaplasty [17]. The negative effect of cigarette smoking on wound healing is well-known. The decrease in the incidence of certain vessels detected in smoking patients appears to be the reason for this increase in complications.

While a number of reduction techniques have been proposed in the literature according to the classification of labia minora width, we did not find any recommendations on the right technique based on labia minora morphology [18]. When determining the vascularity of tissue, the outlet of the main artery was found to extend perpendicular to the most lateral prominence of the labium minus. Accordingly, the central vessel was observed to be below the midpoint in labia minora with a lower morphology. However, the central vessel was above the midpoint in labia minora with an upper morphology and was in the middle of labia minora with a middle morphology as described by Georgiou et al. [9]. Since the percentage of central vessels was statistically higher in labia minora with an upper morphology compared to labia with a lower morphology, this shows that it is important to consider the extent of interruption to the central vasculature during anterior wedge resection. As the central vessel is quite low down in labia with a lower morphology, the posterior vessel originates from the central vessel. This means that blood flow is significantly reduced if posterior wedge resection is carried out in labia minora with a lower morphology because the main artery is cut ( $\mathbf{F i g . ~ 6 ) . ~ T h e ~}$ Posterior 1 vessel was found to be significantly higher in labia minora with a middle morphology compared to the other morphologies. This explains why posterior and central wedge resection reduces blood flow and why this technique has higher rates of dehiscence [9]. When all labia minora with an upper morphology were evaluated, the incidence of Posterior 1 and 2 vessels was found to be higher in labia with an upper morphology compared to labia with a lower morphology. Since the central vessel runs though the upper part of the long axis of the labium minus with an upper morphology, the higher incidence of posterior vessels was to be expected. According to the vascularity map, posterior wedge resection is the procedure most likely to protect the main vessel when performed in labia with an upper morphology. The central vessel would be cut if central wedge resection is carried out in labia with a middle morphology. If posterior wedge resection is performed, a narrow wedge angle would be preferable. Our 


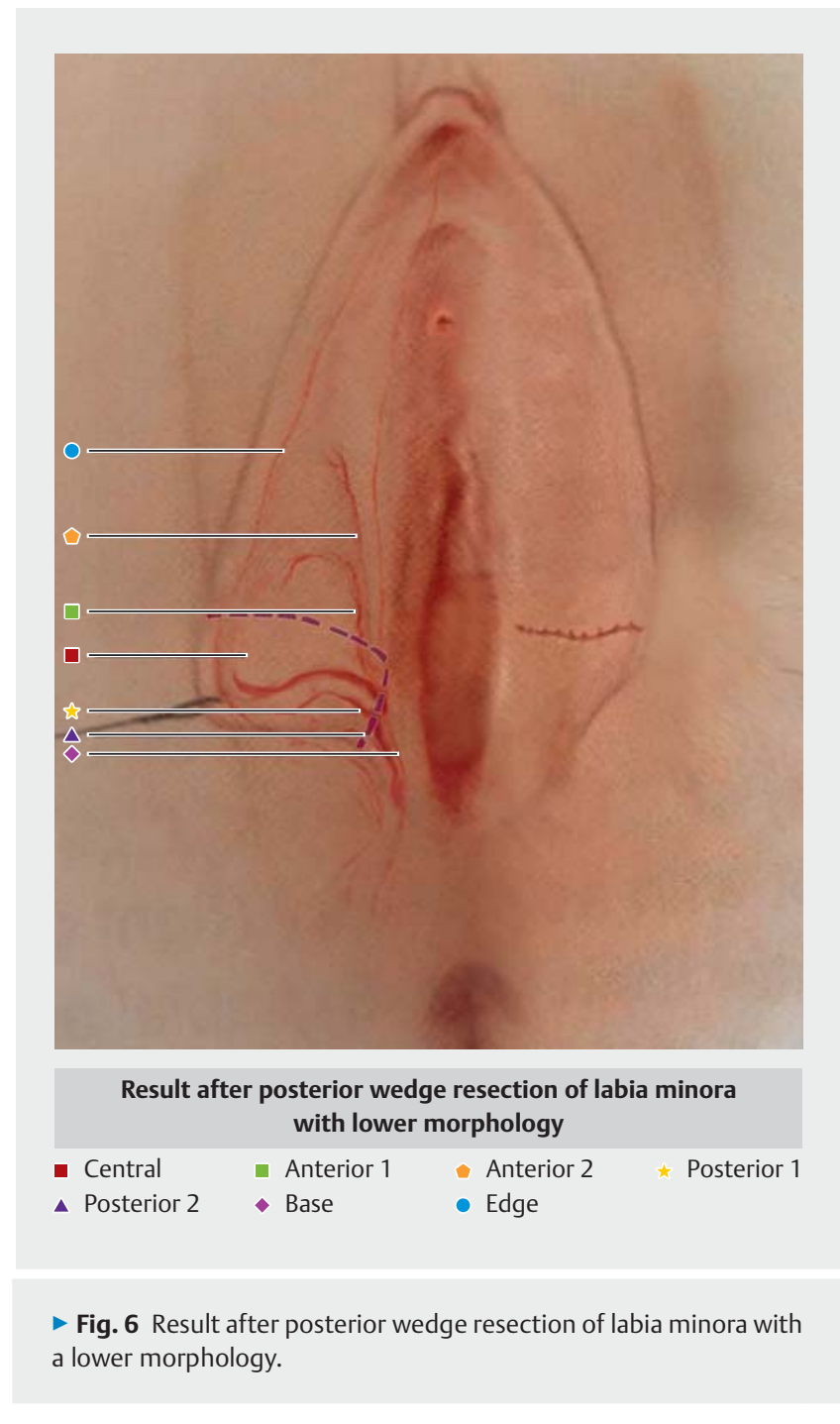

data suggest that trimming could be more reliable than wedge resection in terms of wound complications. The success of surgery is multifactorial. Tissue vascularity may be just one of the factors influencing the choice of technique. Our results were obtained from a limited number of patients from our region who did not represent the entire population. However, a vascularity map can be created for each patient in a very short time. This would allow the surgeon to choose the appropriate approach for the patient. Each woman must be mapped individually. It is important to specifically identify the central artery, and the procedure which has the lowest impact on the central artery should be chosen.

The vascularity of the labium minus can differ in patients with different labial morphologies, sizes, and characteristics. The procedure to determine vascularity does not take long, and it is neither invasive nor harmful to the patient. We recommend that plastic surgeons and gynecologists who perform labiaplasty assess the patient's vascularity prior to surgery. We believe that the incidence of dehiscence - the most common complication of labiaplasty - could be reduced by avoiding the resection of tissue from areas with high vascularity, particularly when the central vessel is involved.

\section{Conclusion}

Differences in morphology and vascularity may result in the different rates of dehiscence reported in the literature. The assessment of vascularity using a cold light source can help guide the choice of surgical technique and determine the amount and shape of the tissue to be resected.

\section{Authorship Credits}

The authors declare that they are qualified for authorship and that each author has sufficiently participated in the work to take public responsibility for appropriate portions of the content. The authors declare that all authors made a substantial contribution to the concept or design of the work, or the acquisition, analysis or interpretation of data, or drafted the article, or revised it critically with regard to important intellectual content and approved the version to be published.

\section{Conflict of Interest}

The authors declare that they have no conflict of interest. Authors declare that no funding or any type of sponsorship was received.

\section{References}

[1] Hunter JG. Labia Minora, Labia Majora, and Clitoral Hood Alteration: Experience-Based Recommendations. Aesthet Surg J 2016; 36: 71-79

[2] Cosmetic Surgery National Data Bank Statistics. Aesthet Surg J 2015; 35 (Suppl. 2): 1-24

[3] Clerico C, Lari A, Mojallal A et al. Anatomy and Aesthetics of the Labia Minora: The Ideal Vulva? Aesthetic Plast Surg 2017; 41: 714-719

[4] Gulia C, Zangari A, Briganti V et al. Labia minora hypertrophy: causes, impact on women's health, and treatment options. Int Urogynecol ] 2017; 28: 1453-1461

[5] Zwier S. "What motivates her": motivations for considering labial reduction surgery as recounted on women's online communities and surgeons' websites. Sex Med 2014; 2: 16-23

[6] Oranges CM, Sisti A, Sisti G. Labia minora reduction techniques: a comprehensive literature review. Aesthet Surg J 2015; 35: 419-431

[7] Alter G]. Labia minora reconstruction using clitoral hood flaps, wedge excisions, and YV advancement flaps. Plast Reconstr Surg 2011; 127: 2356-2363

[8] Lipscomb GH, Ling FG. Wound Healing, Suture Material, and surgical Instrumentation. In: Rock JA, Jones HW III, eds. Te Linde's Operative Gynecology. 9th ed. Philadelphia, PA: Lippincott Williams \& Wilkins; 2003: 233-239

[9] Georgiou CA, Benatar M, Dumas P et al. A Cadaveric Study of the Arterial Blood Supply of the Labia Minora. Plast Reconstr Surg 2015; 136: 167178

[10] Hwang WY, Chang TS, Sun P et al. Vaginal reconstruction using labia minora flaps in congenital total absence. Ann Plast Surg 1985; 15: 534-537

[11] Hamori CA, Banwell PE, Alinsod R. Female cosmetic genital Surgery. Concepts, Classification, and Techniques. New York: Thieme; 2017 
[12] Motakef S, Rodriguez-Feliz ], Chung MT et al. Vaginal labiaplasty: current practices and a simplified classification system for labial protrusion. Plast Reconstr Surg 2015; 135: 774-788

[13] Puppo V. Anatomy and physiology of the clitoris, vestibular bulbs, and labia minora with a review of the female orgasm and the prevention of female sexual dysfunction. Clin Anat 2013; 26: 134-152

[14] Rouzier R, Louis-Sylvestre C, Paniel B] et al. Hypertrophy of labia minora: experience with 163 reductions. Am J Obstet Gynecol 2000; 182: 35-40

[15] Munhoz AM, Filassi JR, Ricci MD et al. Aesthetic labia minora reduction with inferior wedge resection and superior pedicle flap reconstruction. Plast Reconstr Surg 2006; 118: 1237-1247
[16] Ouar N, Guillier D, Moris V et al. Postoperative complications of labia minora reduction. Comparative study between wedge and edge resection. Ann Chir Plast Esthet 2017; 62: 219-223

[17] Bucknor A, Chen AD, Egeler S et al. Labiaplasty: Indications and Predictors of Postoperative Sequelae in 451 Consecutive Cases. Aesthet Surg J 2018; 38: 644-653

[18] Mayer HF, Elizalde ML, Duh N et al. Bidimensional labia minora reduction. Eur J Plast Surg 2011; 34: 345-350 